\title{
Understanding Abiotic and Biotic Conditions in Post-Mining Pit Lakes for Efficient Management: A Case Study (Poland)
}

\author{
Włodzimierz Marszelewski $^{1} \cdot$ Ewa A. Dembowska ${ }^{2} \cdot$ Paweł Napiórkowski $^{2} \cdot$ Adam Solarczyk $^{1}$
}

Received: 26 February 2016 / Accepted: 18 January 2017 / Published online: 20 February 2017

(C) The Author(s) 2017. This article is published with open access at Springerlink.com

\begin{abstract}
This study was aimed at determining whether the origin, morphometry, and hydrology of post-mining lakes affect their hydrochemical and hydrobiological parameters (i.e. water quality). The investigated post-mining lakes were very young compared to glacial lakes and represent early stages of ecosystem succession. Despite their different ages and morphometries, they are all mesotrophic and have good water quality. They have not been supplied with phosphorus and nitrogen, which can cause excessive development of pelagic phytoplankton; as a result, they share low chlorophyll $a(\mathrm{Chl} a$ ) content, low phytoplankton biomass, and relatively high water transparency. Low abundance and species richness of zooplankton indicate low trophic levels in all of the lakes. Chl $a$ in Lakes Przykona and Bogdałów were within the range typical of mesotrophic lakes, while Lake Janiszew had very low Chl $a$, typical of an oligotrophic water body. The low N:P ratios (4-6), especially in summer, indicates nitrogen limitation of primary production. There is a risk that such a proportion of the major biogenic elements could lead to harmful cyanobacterial blooms. The lake basins were formed using quaternary deposits (sand, clay) at their bottoms; as a result,
\end{abstract}

Electronic supplementary material The online version of this article (doi:10.1007/s10230-017-0434-8) contains supplementary material, which is available to authorized users.

Paweł Napiórkowski

pnapiork@umk.pl

1 Department of Hydrology and Water Management, Faculty of Earth Sciences, Nicolaus Copernicus University, Lwowska 1, 87-100 Toruń, Poland

2 Department of Hydrobiology, Faculty of Biology and Environmental Protection, Nicolaus Copernicus University, Lwowska 1, 87-100 Toruń, Poland the lakes had a slightly alkaline $\mathrm{pH}(>8)$, which favors the development of aquatic organisms. Optimum depth helps establish lake stratification and ensures ecological stability. This applies to post-mining lakes as well; an optimum depth should be determined to ensure the development of thermal stratification, which affects lake processes.

Keywords Artificial lakes · Hydro-morphometry · Hydrochemistry · Plankton indices · Trophic state

\section{Introduction}

Global environmental change (global warming), together with local environmental change (e.g. the economic exploitation of catchment areas), affect the water balance in many regions (Bockelmann et al. 2004). Extracting rock or minerals from the earth disrupts the natural flow of surface water and groundwater (Nixdorf et al. 2005; Schultze et al. 2010; Soni et al. 2014). In addition, open pit mining leaves voids with maximum depths that may exceed $200 \mathrm{~m}$. The reclamation of such areas typically involves transforming the exhausted pits into pit lakes by artificial flooding or allowing the pits to fill naturally through hydrological processes such as precipitation and groundwater infiltration (Gammons et al. 2009, 2013). The quality of water in pit lakes is difficult to predict and depends on many factors, including groundwater quality and the geologic structure of the area.

Post-mining lakes can be used for recreational purposes (Doupé and Lymbery 2005), can provide new habitats in areas where human activity has degraded wetlands (Brenner et al. 1987; Doupé and Lymbery 2005; Klapper and Geller 2001), and can be used for fish farming (Axler et al. 1996a, b). Such uses can affect lake water quality, 
so regular monitoring of hydrological, hydrochemical, and hydrobiological parameters of these fragile ecosystems is highly recommended (Doupé and Lymbery 2005).

This study presents the hydro-morphometry as well as hydrochemical and hydrobiological parameters of lakes created at three abandoned lignite mining pits in central Poland (Fig. 1), which had been filled in with debris and flooded after mine dewatering ceased. Formed between 4 and 20 years ago, the lakes are at different stages of ecosystem succession. Ecosystems of this kind have not yet undergone a comprehensive investigation based on morphometric measurements, physical, chemical, and biological analysis, and ecological evaluation. This study evaluated the morphometry of the lakes and determined their chemical composition and biological condition. These parameters are all necessary to assess whether the lakes are suitable for further development as recreational sites or/and water supply reservoirs. Representing an early stage of ecological succession, these aquatic ecosystems will provide valuable information on subsequent phases of this process.

It was assumed that the investigated lakes, all in early succession, have good water quality and low trophic state. It was also assumed that determining the lake morphometry (optimum depth and shape of the basins) will help to maintain good water quality and low trophy, despite increasing anthropogenic pressure.

\section{Materials and Methods}

\section{Sampling Sites}

The investigated mines lie within the Teleszyna and Kiełbaska river basins. Before mining was initiated (1934), the local river system was well-developed, which indicates the presence of shallow groundwater (Supplementary file 1A). The forests were not very dense. Significant changes in the landscape were caused by lignite mining at the Adamów, Bogdałów, and Władysławów open pit mines (outside of the investigated area), starting in 1959. The river system underwent severe changes, particularly in the middle section of the Teleszyna River. The TeleszynaKiełbaska Canal was built to increase water supply for the coal-fired power station (Supplementary file 1B). An external spoil tip (dump) was built and forested, thus increasing the wooded area near the open pit mines.

After mining ended, the abandoned pits were used as internal spoil tips for the new Koźmin and Adams mines (in the western part of the mined area). The abandoned pits were filled to the level of the surrounding area, mainly with

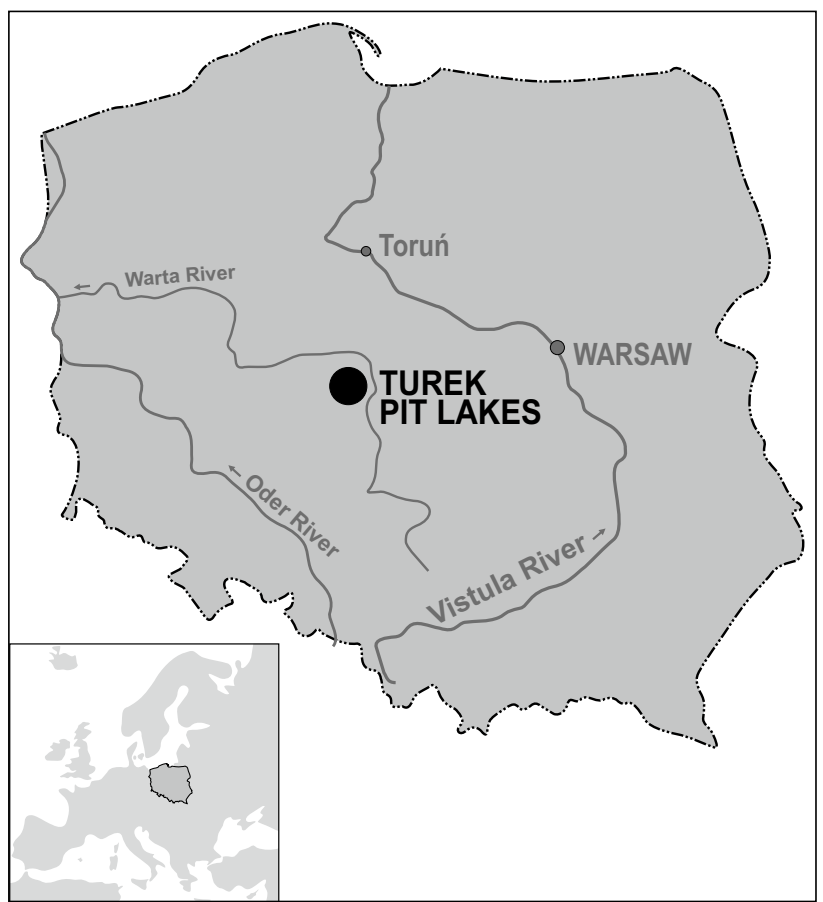

Fig. 1 Location of investigated area

materials from quaternary deposits. Some of these were planted with trees or used for agriculture. The first pit filled with water was the Bogdałów mine; Lake Bogdałów was created in 1994, originally only as a water reservoir for firefighting. This pioneering method of land reclamation provided the basis for a new concept of a hydrographic network focused on the creation of lakes in the abandoned pits (Supplementary file 1C). The project, as prepared by the KWB Adamów SA lignite mine, included Lake Bogdałów in the new water system and required the use of hydraulic machinery.

Przykona was the first lake created as part of the project, followed by Lake Janiszew. Both were built within the internal spoil tips and only occupy part of them. The rest of the dump areas were forested or used for farming. The lake basins have regular shapes, flat bottoms and gently sloping shores. They were formed using glacial sediments, including tills, which were used to seal the bottoms. The basins do not touch quaternary deposits located near the reclaimed pits.

Lakes Przykona and Janiszew are situated in the immediate vicinity of the operating Adamów and Koźmin mines. In addition, they are located within the impact zone of the cones of depression of the open pits, but the lake bottoms do not border the Miocene sediments that contain the lignite. Along the coastlines are wastelands, recreational areas 
(Przykona), and fields (Janiszew). There are no forests, which would normally reduce the impact of wind on mixing and limit nutrient export from the catchment area. Only the area surrounding Lake Bogdałów has been fully shaped and, together with the lake, is considered a semi-natural geo-ecosystem. The forest around Lake Bogdałów ensures lake water stability during the summer.

Lake basins, formed during internal dumping, were gradually filled with water of different origins. Lake Bogdałów was filled by natural inflow of groundwater percolating through Quaternary and Miocene sediments (1993-1994). Lake Przykona was filled with water from the upper Teleszyna River, flowing through the TeleszynaKiełbaska Canal, and with water from dewatering of the Adamów mine; groundwater did not play an important role. The water level in this lake is maintained by adjustment of a floodgate at the dam. In 2008, the Lake Janiszew basin was filled with water from dewatering of the Adamów mine.

We investigated three abandoned lignite mining pits. The Bogdałów pit lake $\left(52^{\circ} 2^{\prime} 49^{\prime \prime} N, 1^{\circ} 36^{\prime} 13^{\prime \prime} E\right.$; Supplementary file 2; Table 1) has a surface area of 11.6 ha and a maximum depth of $11.7 \mathrm{~m}$; it is the smallest and deepest of the three lakes. The lake is surrounded by mixed coniferous forests. Due to the shape of the basin, the littoral zone forms a rather narrow band dominated by common reed (Phragmites australis) and dense communities of Typha angustifolia. Charophytes are found at a depth of several meters.

The Przykona pit lake $\left(52^{\circ} 0^{\prime} 20^{\prime \prime} \mathrm{N}, 18^{\circ} 39^{\prime} 20^{\prime \prime} \mathrm{E}\right.$; supplementary file 3, Table 1) has a surface area of 142.4 ha and a maximum depth of $7.6 \mathrm{~m}$; it is the largest and shallowest of the three lakes. Dense stands of common reed in the littoral zone form an effective biogeochemical barrier. There are occasional shallow places with large communities of submerged vegetation dominated by pondweeds (Potamogeton) and stoneworts (Charales).

The Janiszew pit lake $\left(52^{\circ} 05^{\prime} 06^{\prime \prime} \mathrm{N}, 18^{\circ} 37^{\prime} 48^{\prime \prime} \mathrm{E}\right)$ has a surface area of 63.5 ha (Supplementary file 4; Table 1) and pioneer vegetation. The littoral zone is not yet fully developed, and only single aquatic plants are found in several places. The lake offers perfect conditions for investigating primary succession. The following plant species have been identified: water knotweed (Persicaria amphibia), branched bur-reed (Sparganium erectum), European burreed (Sparganium emersum), common club-rush (Schoeneoplectus lacustris), common reed (Phragmites australis), common water-crowfoot (Ranunculus aquatilis), Canadian waterweed (Elodea canadensis), reed mannagrass (Glyceria maxima), common bulrush (Typha latifolia), common spike-rush (Eleocharis palustris), calamus (Acorus calamus), common rush (Juncus effusus), and shining pondweed (Potamogeton lucens).
Table 1 Morphometric data of pit lakes

\begin{tabular}{|c|c|c|c|}
\hline & Przykona & Bogdałów & Janiszew \\
\hline Location & $\begin{array}{l}52^{\circ} 0^{\prime} 20^{\prime \prime} \mathrm{N} \\
18^{\circ} 39^{\prime} 20^{\prime \prime} \mathrm{E}\end{array}$ & $\begin{array}{l}52^{\circ} 2^{\prime} 49^{\prime \prime} \mathrm{N} \\
18^{\circ} 36^{\prime} 13^{\prime \prime} \mathrm{E}\end{array}$ & $\begin{array}{l}52^{\circ} 05^{\prime} 06^{\prime \prime} \mathrm{N} \\
18^{\circ} 37^{\prime} 48^{\prime \prime} \mathrm{E}\end{array}$ \\
\hline Area of reservoir (ha) & 142.4 & 11.6 & 63.5 \\
\hline Max. depth (m) & 7.6 & 11.7 & 10.5 \\
\hline Average depth (m) & 4.3 & 4.7 & 6.9 \\
\hline Max. length (m) & 1881 & 927 & 1138 \\
\hline Max. width (m) & 1121 & 156 & 762 \\
\hline $\begin{array}{l}\text { Indicator of reservoir } \\
\text { shape }\end{array}$ & 0.57 & 0.40 & 0.66 \\
\hline Exposure index & 33.1 & 2.5 & 9.2 \\
\hline Osgood Index ${ }^{a}$ & 3.6 & 13.8 & 8.7 \\
\hline Gradient of depth ${ }^{b}$ & 1.2 & 2.4 & 1.8 \\
\hline $\begin{array}{l}\text { Schmidt stability }(\mathrm{g} \mathrm{cm} \\
\mathrm{cm}^{-2} \text { ) }\end{array}$ & 13.98 & 67.27 & 61.31 \\
\hline
\end{tabular}

$L_{e f}$ effective length $(\mathrm{km}), W_{e f}$ effective width $(\mathrm{km})$

${ }^{\mathrm{a}} \mathrm{OI}=\mathrm{Z} / \mathrm{A}_{0}{ }^{0.5}$ where $\boldsymbol{Z}$-mean depth; $\mathrm{A}_{0}$ - surface area $\left(\mathrm{km}^{2}\right)$

${ }^{\mathrm{b}} \mathrm{F}=\mathrm{Z}_{\mathrm{max}} / 785\left(\mathrm{~L}_{\mathrm{ef}}+\mathrm{W}_{\mathrm{ef}}\right)^{0.28}$ where $Z_{\mathrm{max}}$-max. depth (m)

\section{Methods}

Sampling was conducted seasonally: in summer (15-18 Aug. 2011), autumn (17-19 Nov. 2011), winter (17-18 Feb. 2012, shortly before the ice melt), and spring (13-15 Apr. 2012). Prior to the sampling, we measured the depths of the lakes using an echosounder synchronized with a GPS receiver (4150 measurements in total, so-called trackpoint). Subsequently, we prepared bathymetric maps and charts. The rate of water exchange in Lake Przykona was calculated using published data (Polak and Klich 2009). The depth gradient (F) was calculated based on a study by Mietz (LAWA 1998, after Mietz 1991).

Physico-chemical and hydrobiological parameters were measured in the deepest parts of the lakes. We measured temperature from the surface to the bottom $\left(\mathrm{T},{ }^{\circ} \mathrm{C}\right)$, dissolved oxygen concentration in the water column, water saturation (DO, $\mathrm{mg} \mathrm{L}^{-1}, \%$ ), Secchi depth (SD, m), water $\mathrm{pH}$, and electrical conductivity $\left(\mathrm{EC}, \mu \mathrm{S} \mathrm{cm}^{-1}\right)$. All physicochemical parameters were measured using a WTW Oxi 197 probe (T, DO) and WTW MultiLine $\mathrm{P} 4$ probe $(\mathrm{pH}, \mathrm{EC})$.

The chlorophyll $a$ content $\left(\mathrm{Chl} a, \mu \mathrm{g} \mathrm{L}^{-1}\right)$ was determined using the Nusch (1980) method. The concentration of total phosphorus (TP), $\mathrm{PO}_{4}{ }^{3-}, \mathrm{NH}_{4}{ }^{+}, \mathrm{NO}_{2}{ }^{-}$, and $\mathrm{NO}_{3}{ }^{-}$was determined by colorimetric assays using a UV-VIS Lambda 25 (Perkin Elmer) spectrophotometer. Total nitrogen (TN), total inorganic carbon (TIC), and total carbon (TC) were determined using a Shimadzu TOC- $\mathrm{V}_{\mathrm{CSN}}$ analyzer, which had a TNM-1 attachment. The concentrations of $\mathrm{Cl}^{-}, \mathrm{SO}_{4}{ }^{2-}, \mathrm{Na}^{+}, \mathrm{Ca}^{2+}, \mathrm{K}^{+}, \mathrm{Mg}^{2+}, \mathrm{Br}^{-}$, $\mathrm{Li}^{+}$, and $\mathrm{F}^{-}$were determined using a Dionex ICS-3000 ion 
chromatograph. The $\mathrm{Mn}, \mathrm{Fe}, \mathrm{Be}, \mathrm{Al}, \mathrm{V}, \mathrm{Cr}, \mathrm{Co}, \mathrm{Ni}, \mathrm{Cu}, \mathrm{Zn}$, $\mathrm{Ga}$, As, Se, Rb, Sr, Ag, Cd, In, Cs, Ba, Tl, Pb, Bi, U, and Mo concentrations were determined by an inductively coupled plasma mass spectrometry (ICP-MS) using an Elan ICP-MS (Perkin Elmer) emission spectrometer. The detection limits of most were below $0.01 \mu \mathrm{g} \mathrm{L}^{-1}$.

Biological studies included determining the species composition, abundance (ind. $\mathrm{L}^{-1}$ ), and biomass (wet weight, $\mathrm{mg} \mathrm{L}^{-1}$ ) of phytoplankton and zooplankton. Samples for analysis of phytoplankton species composition were collected with a plankton net with $25 \mu \mathrm{m}$ mesh diameter and taxonomically identified (Hindák 2008; Javornickỳ 2003; Komárek and Anagnostidis 2007, 2008; Komárek and Fott 1983; Komárek and Zapomelova 2007; Krammer and Lange-Bertalot 1986, 1988, 1991a, b; Popovskỳ and Pfiester 1990; Starmach 1968, 1974, 1983; Wołowski 1998; Wołowski and Hindák 2005). For quantitative analysis, the samples were not concentrated; they were immediately preserved with Lugol's solution ( $\mathrm{J}$ in KJ). Planktonic organisms fixed with Lugol's solution do not change their size or shape. This is extremely important since plankton biomass is calculated based on the size of planktonic organisms. The abundance of algae was determined using the method of Utermöhl (1958), in which their biomass is measured volumetrically (Hillebrand et al. 1999; Sun and Liu 2003), assuming that $1 \mathrm{~mm}^{3}$ of algae is equal to $1 \mathrm{mg}$ (Elser and Carpenter 1988). To assess the similarity between phytoplankton species composition, the Jaccard's coefficient was calculated using MVSP 3.2 software (Kovach 2010).

For quantitative analysis of zooplankton, $10 \mathrm{~L}$ of water was collected with a Patalas trap and strained through a mesh net (mesh diameter of approx. $25 \mu \mathrm{m}$ ). All samples were preserved with Lugol's solution (Nogrady et al. 1993; Harris et al. 2000). Altogether, 12 qualitative and quantitative samples were collected. Identification and measurement of zooplankton was conducted using a light microscope Nikon Alphaphot YS2, a Panasonic camera, MultiScan, and associated software for image analysis. Zooplankton were counted using a microscope in a Segdwick-Rafter chamber by the sub-sampling method (McCauley 1984). The zooplankton abundance was calculated per volume in $1 \mathrm{~L}$ of water, and were identified using available studies (Radwan 2004; Rybak and Błędzki 2010). The wet weight of rotifers was calculated using Radwan's formula (2004).

The trophic state index (TSI) of the studied lakes was calculated from the: SD, Chl $a$, TP, and TN (Carlson 1977; Kratzer and Brezonik 1981). The rotifer trophic state index (TSI ${ }_{\text {Rot }}$ ) was calculated after Ejsmont-Karabin (2012). The stratification force, which is defined as the energy required to convert the vertical distribution of water density to uniform density in the water column by blending, but without heat gain or heat loss, is expressed using the Schmidt stability index (S), which is calculated using the formula proposed by Schmidt (1928) and Idso (1973).

\section{Results}

\section{Hydrology and Morphometry of the Pit Lakes}

In hydrographic terms, Lake Bogdałów is exorheic, while Lakes Przykona and Janiszew are flow-through. However, during the study period, Lakes Bogdałów and Janiszew were both endorheic (no surface water outflow was observed) and the water exchange rate, $\rho(\mathrm{Q} / \mathrm{V})$, which was calculated based only on regular hydrological measurements (water level, volume of outflow) was low. It was assumed to be 0.06 year $^{-1}$ during the study period. Total outflow of water from Lake Przykona, i.e. surface and underground (the lake is located within the cone of depression of the Adamów mine) was $0.087 \mathrm{~m}^{3} \mathrm{~s}^{-1}$. The water exchange rate in Lake Przykona was 0.45 year $^{-1}$. Thus, the water exchange rate in all three lakes was low.

The lakes vary greatly in size and volume (Table 1; Supplementary files 2-4). With a volume of $5.49 \times 10^{5}$ $\mathrm{m}^{3}$, Lake Bogdałów is the smallest. Lake Przykona is the largest (volume of lake reach $60.99 \times 10^{5} \mathrm{~m}^{3}$ ). The maximum depths range from only $7.6 \mathrm{~m}$ (Przykona) to $11.7 \mathrm{~m}$ (Bogdałów). The shape of Bogdałów (0.40) resembles an inverted cone, Przykona (0.57), a paraboloid, and Janiszew (0.66), an ellipsoid. Lake basin shape and wind exposure both affect water mixing.

Lake Przykona has the highest exposure index (33.1) and Lake Bogdałów, the lowest (2.5). The depth gradient indicates that Przykona is polymictic $(\mathrm{F}<1.5)$. Morphometric parameters of Bogdałów and Janiszew provide conditions for summer thermal stratification $(F>1.5)$. These thermal conditions were confirmed by the Schmidt stability index, which exceeds $60 \mathrm{~g} \mathrm{~cm} \mathrm{~cm}^{-2}$ in both lakes.

In the future, phosphorus compounds accumulated in the sediments of Przykona and Janiszew could be released from the bottom layer into the euphotic zone by intensive water mixing, which would stimulate phytoplankton growth (Osgood index < 7) (Osgood 1988). In Bogdałów, it appears that phosphorus inflow from the bottom sediments is occurring during the growing season (Table 1).

\section{Physical and Chemical Parameters}

The lakes have different thermal structures. The average temperature in the surface layer ranged from $8.8^{\circ} \mathrm{C}$ in Lake Przykona to $9.8^{\circ} \mathrm{C}$ in Lake Bogdałów. During summer, water temperature in Przykona was uniform (Fig. 2). In Janiszew, the epilimnion reached a depth of $8 \mathrm{~m}$; the maximum thermal gradient in the metalimnion 
was $4.5^{\circ} \mathrm{C} \mathrm{m}^{-1}$. The deepest lake, Bogdałów, had all of the thermal layers; the epilimnion reached a depth of $5 \mathrm{~m}$, while the metalimnion had a thickness of $3 \mathrm{~m}$, and its maximum thermal gradient was $3.6^{\circ} \mathrm{C} \mathrm{m}^{-1}$. Water temperature in the hypolimnion was not uniform, but gradually decreased with depth $\left(9.8^{\circ} \mathrm{C}\right.$ at the bottom; Fig. 2). In autumn, the lakes experienced turnover (cold and warm waters mixed and readjusted), which is typical of natural standing waters. When the lakes were covered with ice, inverse water thermal stratification occurred: the temperature increased with depth, ranging from $\approx 0{ }^{\circ} \mathrm{C}$ immediately under the ice layer to $3.4^{\circ} \mathrm{C}$ in Przykona and to $4.1{ }^{\circ} \mathrm{C}$ in Janiszew. Spring homeothermy could be observed in all three lakes, but was the shortest in Bogdałów (Fig. 2).

The highest average water transparency $(7.8 \mathrm{~m})$ was recorded in Lake Janiszew. The lowest $(4.4 \mathrm{~m})$ was recorded in Lake Przykona. In Lake Bogdałów, water transparency reached $5.6 \mathrm{~m}$ (Table 2).

Differences in DO in the lakes were observed in summer. In the surface layer, it ranged from $10.9 \mathrm{mg} \mathrm{L}^{-1}$ in Lake Przykona to $9 \mathrm{mg} \mathrm{L}^{-1}$ in Lake Bogdałów (Table 2; Fig. 2). The largest differences in DO were observed in the lakes' bottom layers, where it ranged from no oxygen (anaerobic conditions) in Bogdałów, to $0.5 \mathrm{mg} \mathrm{L}^{-1}$ (trace amounts) in Janiszew, to $4.2 \mathrm{mg} \mathrm{L}^{-1}$ in Przykona. In other seasons, DO was high and ranged from $\approx 80$ to $120 \%$ (i.e. from $\approx 9$ to $15 \mathrm{mg} \mathrm{L}^{-1}$ ).

All the lakes were weakly alkaline, with the median pH ranging from 8.2 in Bogdałów to 8.4 in Przykona. The lowest average EC $\left(411 \mu \mathrm{S} \mathrm{cm}^{-1}\right)$ was recorded in Przykona and the highest $\left(833 \mu \mathrm{S} \mathrm{cm}^{-1}\right)$, in Bogdałów (Table 2).

The average TP ranged from $0.034 \mathrm{mg} \mathrm{L}^{-1}$ in Janiszew to $0.046 \mathrm{mg} \mathrm{L}^{-1}$ in Przykona (supplemental file 5). The average $\mathrm{TN}$ ranged from $0.327 \mathrm{mg} \mathrm{L}^{-1}$ in Bogdałów to $0.546 \mathrm{mg} \mathrm{L}^{-1}$ in Przykona (Table 2). The N:P ratio in the lakes ranged from 4 to 25. In August, primary production in all lakes was limited by nitrogen and in spring, by phosphorus (the N:P ratio ranged from 22 to 24). The lowest average $\mathrm{Chl}$ a content was recorded in Janiszew: $0.89 \mu \mathrm{g}$ $\mathrm{L}^{-1}$ and the highest, in Przykona: $3.03 \mu \mathrm{g} \mathrm{L}^{-1}$ (Table 2).

Iron and $\mathrm{Mn}$ concentrations were low and did not vary much seasonally. Fluoride and $\mathrm{Br}$ concentrations were also low (supplemental file 6). The lakes are supplied primarily by groundwater from the dewatering of the operating mines. Most of the contaminants in the water originate from local aquifers situated at different depths (from several to more than $100 \mathrm{~m}$ ). Only $\mathrm{Cu}$ and $\mathrm{Cd}$ slightly exceeded limit values in Przykona $\left(83.14 \mu \mathrm{g} \mathrm{Cu} \mathrm{L} \mathrm{L}^{-1}\right.$; $\left.1.24 \mu \mathrm{g} \mathrm{Cd} \mathrm{L}^{-1}\right)$ and Bogdałów $\left(83.20 \mu \mathrm{g} \mathrm{Cu} \mathrm{L}^{-1} ; 1.14 \mu \mathrm{g}\right.$ $\left.\mathrm{Cd} \mathrm{L}^{-1}\right)$. The limit for $\mathrm{Pb}$ was also exceeded in all of the lakes (Przykona-7.71 $\mu \mathrm{g} \mathrm{L}^{-1}$; Bogdałów-7.24 $\mu \mathrm{g} \mathrm{L}^{-1}$; Janiszew-9.06 $\mu \mathrm{g} \mathrm{L}^{-1}$ ) (supplemental file 7). The concentration of the remaining chemical parameters can be found in supplemental file 6 .

\section{Plankton}

Phytoplankton of the studied pit lakes was composed of 100 taxa of prokaryotic and eukaryotic algae (supplemental
Fig. 2 Temperature profiles and oxygen profiles of the studied pit lakes: (1) Przykona; (2) Bogdałów; (3) Janiszew

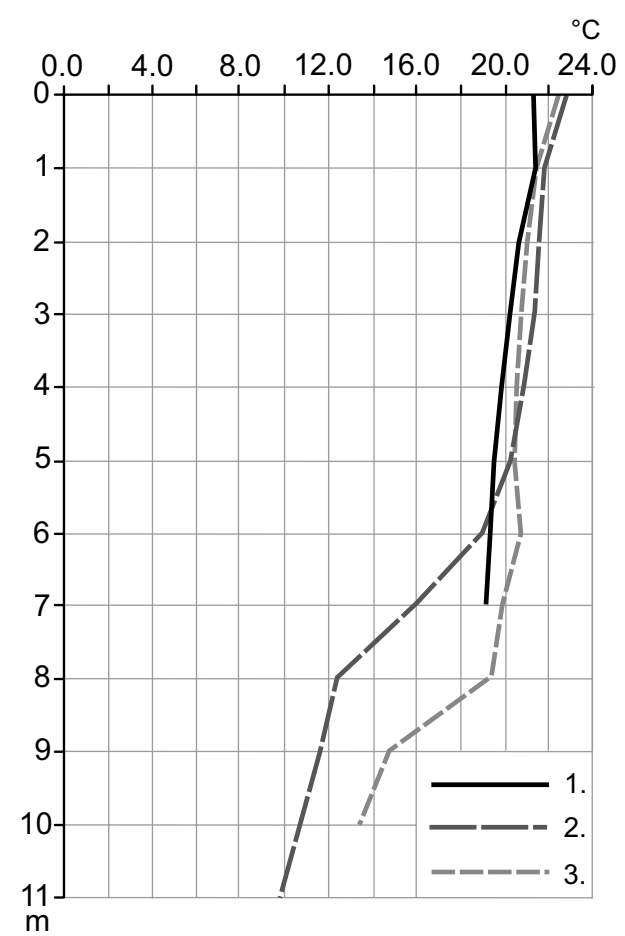

$\mathrm{mgO}_{2} \mathrm{~L}^{-1}$

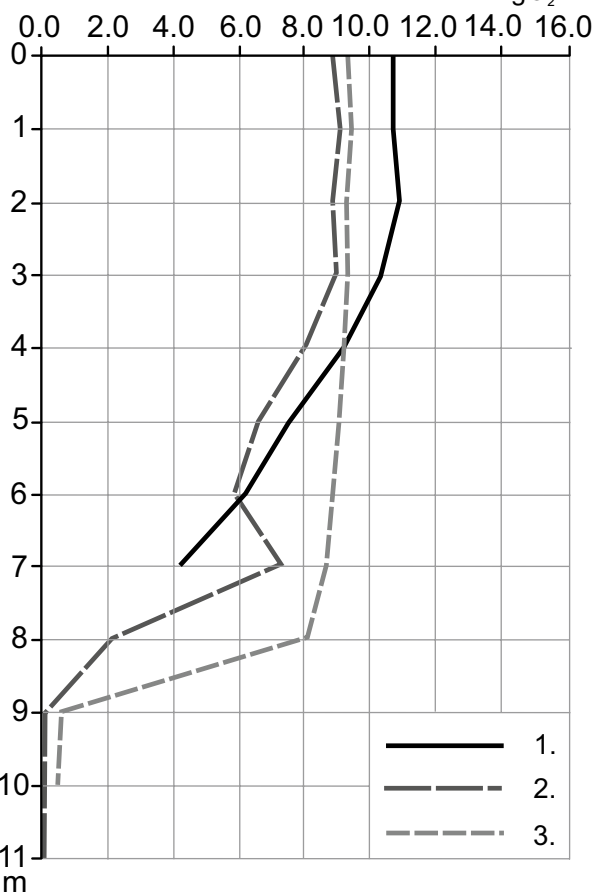


Table 2 Physico-chemical data and basic biological data of pit lakes

\begin{tabular}{|c|c|c|c|c|c|c|}
\hline & \multicolumn{2}{|l|}{ Przykona } & \multicolumn{2}{|c|}{ Bogdałów } & \multicolumn{2}{|l|}{ Janiszew } \\
\hline & Average & Range & Average & Range & Average & Range \\
\hline $\mathrm{T}\left({ }^{\circ} \mathrm{C}\right)$ & 8.8 & $0.7-21.4$ & 9.8 & $0.8-22.8$ & 9.5 & $0.6-22.5$ \\
\hline $\mathrm{SD}(\mathrm{m})$ & 4.4 & $2.5-6.4$ & 5.6 & $4.6-7.3$ & 7.8 & $5.0-10.0$ \\
\hline $\mathrm{O}_{2}\left(\mathrm{mg} \mathrm{L}^{-1}\right)$ & 12.03 & $10.7-14.1$ & 11.23 & $8.9-14.0$ & 11.55 & $9.3-14.1$ \\
\hline $\mathrm{DO}(\%)$ & 105 & $91-123$ & 99 & $81-109$ & 101 & $91-108$ \\
\hline $\mathrm{pH}$ & 8.39 & $8.20-8.57$ & 8.15 & $8.06-8.32$ & 8.29 & $8.25-8.33$ \\
\hline $\mathrm{EC}\left(\mu \mathrm{S} \mathrm{cm}^{-1}\right)$ & 411 & $377-446$ & 833 & $803-882$ & 757 & $729-796$ \\
\hline Chl $a\left(\mu \mathrm{g} \mathrm{L}^{-1}\right)$ & 3.03 & $1.0-6.28$ & 2.43 & $1.4-4.3$ & 0.89 & $0.53-1.2$ \\
\hline $\mathrm{TP}\left(\mathrm{mg} \mathrm{L}^{-1}\right)$ & 0.046 & $0.021-0.112$ & 0.041 & $0.013-0.114$ & 0.034 & $0.016-0.077$ \\
\hline $\mathrm{TN}\left(\mathrm{mg} \mathrm{L}^{-1}\right)$ & 0.546 & $0.51-0.64$ & 0.327 & $0.26-0.49$ & 0.352 & $0.29-0.40$ \\
\hline $\mathrm{N}_{\text {phyto }}\left(10^{6}\right.$ ind. $\left.\mathrm{L}^{-1}\right)$ & 2.195 & $0.55-4.18$ & 3.452 & $0.70-10.93$ & 0.423 & $0.22-0.80$ \\
\hline $\mathrm{B}_{\text {phyto }}\left(\mathrm{mg} \mathrm{L}^{-1}\right)$ & 3.58 & $0.14-12.19$ & 1.01 & $0.23-3.12$ & 0.23 & $0.11-0.36$ \\
\hline $\mathrm{N}_{\mathrm{zoo}}\left(\right.$ ind. $\mathrm{L}^{-1}$ ) & 134 & $43-405$ & 341 & $27-699$ & 38 & $13-59$ \\
\hline $\mathrm{B}_{\text {zoo }}\left(\mathrm{mg} \mathrm{L}^{-1}\right)$ & 2.095 & $0.67-6.33$ & 0.483 & $0.04-0.99$ & 0.634 & $0.22-0.98$ \\
\hline
\end{tabular}

file 8). Sixty-eight taxa were identified in Lake Bogdałów, 46 in Lake Przykona, and 45 in Lake Janiszew. Bacillariophyceae, Chlorophyta, and Cyanobacteria were represented by the highest number of taxa.

Remarkably, the pit lakes had similar species richness, but different species composition. The Jaccard index of $36 \%$ indicates the greatest similarity between Janiszew and Bogdałów, and the lowest between those lakes and Przykona (29\%). The lakes also differred in terms of phytoplankton abundance and biomass (Table 2). The highest algal biomass was recorded in Przykona $\left(3.6 \mathrm{mg} \mathrm{L}^{-1}\right)$, while it was considerably lower in Bogdałów $\left(\approx 1 \mathrm{mg} \mathrm{L}^{-1}\right)$, and lowest in Janiszew $\left(0.2 \mathrm{mg} \mathrm{L}^{-1}\right)$. In Przykona and Janiszew, Bacillariophyceae and Cryptophyta had the highest average biomass and in Bogdałów, Dinoflagellata and Cryptophyta.

There were few zooplankton species in all three lakes. Over the entire study period, we identified 21 species in Bogdałów and Przykona and 15 in Janiszew (Supplementary file 8). Most of the species were rotifers. The highest number of rotifer species were recorded in Przykona (16) and the lowest, in Janiszew (11). Fifteen rotifer species were identified in Bogdałów.

The average zooplankton abundance in all three lakes was rather low. The highest was recorded in Bogdałów (342 ind. $\mathrm{L}^{-1}$ ), with the greatest contribution (as much as $87 \%$ ) of rotifers (Table 2). The highest zooplankton abundance was also noted in this lake in all four seasons. The average zooplankton abundance in Przykona was 135 ind. $\mathrm{L}^{-1}$, with rotifers accounting for $63 \%$. The lowest average zooplankton abundance was recorded in Janiszew (38 ind. $\left.\mathrm{L}^{-1}\right)$, where crustaceans had the greatest contribution (61\%; Table 2).
Lake Bogdałów was dominated by the following rotifer species: Keratella cochlearis (55\%), Polyarthra longiremis (17\%), and by larval stages of copepods (nauplii; 11\%). In Przykona, eudominants $(>10 \%)$ consisted of larval forms of copepods (28\%) rotifers Trichocerca capucina (16\%), and Polyarthra longiremis (13\%). In Janiszew, larval forms of copepods predominated (35\%), followed by rotifers Polyarthra dolichoptera (15\%) and mature copepods of Eudiaptomus graciloides (11\%).

The highest average zooplankton biomass was recorded in Przykona ( $2.095 \mathrm{mg} \mathrm{\textrm {L } ^ { - 1 }}$ ), with Cladocera contribution as high as $90 \%$. In Janiszew, the zooplankton biomass (0.634 $\mathrm{mg} \mathrm{L}^{-1}$, on average) was also dominated by Cladocera (53\%). The lowest zooplankton biomass was recorded in Bogdałów (0483 $\mathrm{mg} \mathrm{L}^{-1}$ ), where Copepoda had a contribution of $53 \%$ (Table 2).

\section{Trophy Indices}

On the basis of the TSI and the Chl $a$ levels, Przykona and Bogdałów were highly mesotrophic and Janiszew, was oligotrophic. The $\mathrm{TSI}_{\text {Rot }}$ indicates high mesotrophy of Lake Janiszew and the second stage of meso-eutrophy of Lakes Przykona and Bogdałów. The TSI calculated from the TP and TN indicated that the lowest trophic level occurred in Janiszew and the highest in Przykona (Table 3). The average of all trophic level parameters showed the same (Table 3).

\section{Discussion}

Lake processes depend on morphometry and development of the catchment area (Berman 1998; Dodson et al. 2009). 
This applies both to natural and pit lakes. We assessed lake morphometry, which is particularly important for mictic water bodies. Like all polymictic lakes, the shallow Lake Przykona experienced water mixing from top to bottom throughout the year. The deepest lake, Bogdałów, is thermally stratified (although its hypolimnion had a small volume) and is classified as dimictic. Janiszew is partially stratified (a true hypolimnion was not formed), but according to the adopted classification (Wetzel 2001), it is also considered dimictic.

The lakes described in this study have diverse thermal conditions. The highest average temperature in the surface layer was recorded in Bogdałów, which is sheltered from the wind by surrounding forests. The epilimnion extended to a depth of $5 \mathrm{~m}$. In the years 2007-2011, epilimnions of similar thickness (5-6 m) were recorded in Lakes Bachotek, Zbiczno, Ciche, Robotno, and Łąkorz, which are all dimictic, located in deep glacial troughs, and surrounded by high trees (Solarczyk 2013). However, the impact of wind on the thermal structure is stronger in Lake Janiszew, due to its high exposure. The epilimnion had a thickness of $8 \mathrm{~m}$.

The Schmidt stability index exceeds $60 \mathrm{~g} \mathrm{~cm} \mathrm{~cm}^{-2}$ in Bogdałów and Janiszew, due to the differentiation of density and temperature during summer stratification. According to Winder and Schindler (2004), the minimum Schmidt stability index required for stable thermal stratification is $50 \mathrm{~g} \mathrm{~cm} \mathrm{~cm}^{-2}$. The Schmidt index in these lakes calculated for the summer sampling period was not high compared with Lake Moszczonne $\left(690 \mathrm{~g} \mathrm{~cm} \mathrm{~cm}^{-2}\right)$ and Lake Wielickie $\left(830 \mathrm{~g} \mathrm{~cm} \mathrm{~cm}^{-2}\right.$ ) of the Dobrzyń Lake District (Marszelewski 2001). Therefore, early autumn homothermy occurs in Bogdałów and Janiszew during the first half of September. In the future, this type of water mixing, combined with accelerated eutrophication, could cause the inflow of phosphorus compounds from anoxic over-bottom layers to the euphotic zone. This could stimulate autumn algal blooms, a phenomenon which is not observed in deep dimictic lakes, where autumn homothermy begins in the latter half of October.

The above data (on stratification and autumn homeothermy) are extremely important in designing lake basins,

Table 3 Trophic state index (TSI) of studied pit lakes based on SD, Chl $a$, TP, TN and rotifers

\begin{tabular}{llll}
\hline & Przykona & Bogdałów & Janiszew \\
\hline TSI $_{\text {SD }}$ & 38.8 & 35.1 & 30.3 \\
TSI $_{\text {Chl } a}$ & 41.5 & 39.3 & 29.5 \\
TSI $_{\text {TP }}$ & 59.4 & 57.7 & 54.8 \\
TSI $_{\text {TN }}$ & 45.7 & 38.3 & 39.4 \\
TSI $_{\text {Rot }}$ & 50.1 & 50.2 & 42.2 \\
Average TSI & 47.1 & 44.1 & 39.2 \\
\hline
\end{tabular}

particularly their maximum depth. Depth gradient F (the ratio of the maximum and epilimnion depths) can be used to determine the minimum value of the maximum depth that will ensure summer thermal stratification without a hypolimnion. The theoretical depth of epilimnion is a function of the effective length and effective width (e.g. LAWA 1998, after; Ventz 1974; Patalas 1984). According to Mietz (1991), lakes with $\mathrm{F}>1.5$ are stratified during the summer. Therefore, transforming formula (2), and assuming that $\mathrm{F}=1.5$, it is possible to calculate the minimum value of the maximum depth of the lake whose length and width are given. Since the newly created lakes will be initially exposed to wind, their actual dimensions can be treated as the effective dimensions. It should be emphasized that the presence of elements that reduce wind impact, such as forests and hills, increases water mass stability. In Poland, obstacles of this kind should be situated along the western and northwestern shores of post-mining lakes, i.e. based on the direction of prevailing winds.

All three lakes experienced spring homeothermy, whose duration depended on their exposure to the wind. The observed continuous circulation of water in Przykona was due to its morphometrics: large surface area, low average depth (only $4.3 \mathrm{~m}$ ), and a high exposure index. The lake is sensitive to resuspension, a wind-induced process. Accordingly, the lake has the lowest water transparency, caused not only by rapid growth of phytoplankton but also by floating material from resuspension of bottom sediments (Schindler 2006). Lake Janiszew, partially stratified, has characteristics of both lake types.

The most aerobic conditions were recorded in the polymictic lake, Przykona. Lower DO concentrations were recorded in Bogdałów and Janiszew, which were less prone to mixing and had low photosynthetic algae activity. The low DO levels in the bottom layers of Lakes Janiszew and Bogdałów were probably due to the mineralization of organic matter (Bastviken et al. 2004; Müller et al. 2012).

The $\mathrm{pH}$ is the most important parameter for pit lakes, because the mobility of most metals and metalloids is strongly $\mathrm{pH}$-dependent. In addition, most aquatic organisms have a relatively narrow range of $\mathrm{pH}$ tolerance (Soni et al. 2014). Commonly, post-mining pit lakes and lignite pit lakes in particular, have very low $\mathrm{pH}$ (Castro and Moore 2000; Nixdorf et al. 2005; Schultze et al. 2010; Soni et al. 2014). Pit lakes with neutral or acidic $\mathrm{pH}$ have high concentrations of cationic trace metals $\left(\mathrm{Al}^{3+}, \mathrm{Cu}^{2+}, \mathrm{Fe}^{2+} / \mathrm{Fe}^{3+}\right.$, $\mathrm{Mn}^{2+}$, and $\mathrm{Zn}^{2+}$ ) (Schultze et al. 2010; Zauke et al. 1998), posing a real threat to living organisms. The $\mathrm{pH}$ of the studied lakes ranged from 8.06 to 8.57 (Table 2). At this $\mathrm{pH}$, trace metals precipitate and accumulate in sediments. This $\mathrm{pH}$ level, apparently determined by the quality of water from mine dewatering, supports the biocenosis in the lakes. 
The EC of the lakes ranged from 377 to $882 \mu \mathrm{S} \mathrm{cm}^{-1}$, similar to natural eutrophic lakes, e.g. it is $323 \mu \mathrm{S} \mathrm{cm}{ }^{-1}$ in Lake Jeziorak (Dembowska et al. 2015) and $754 \mu \mathrm{S} \mathrm{cm}^{-1}$ in the Vistula oxbow lakes (Dembowska and Napiórkowski 2015). The differences between Przykona $\left(411 \mu \mathrm{S} \mathrm{cm}{ }^{-1}\right)$, Janiszew $\left(757 \mu \mathrm{S} \mathrm{cm}^{-1}\right)$, and Bogdałów $\left(833 \mu \mathrm{S} \mathrm{cm}^{-1}\right)$ are somewhat puzzling. Higher conductivity in Lakes Janiszew and Bogdałów may be due to higher levels of sulphate and chloride.

We did not see significant differences in trace element concentrations in the lakes. Since the lignite pit lakes are supplied by groundwater from different depths, dissolved trace elements come from both tertiary and quaternary aquifers, but in general, the concentrations of microelements in the lakes were low, though the lakes have not yet achieved hydrochemical equilibrium. Concentrations of most of the analyzed elements is legally regulated [Dz. U. (Journal of Laws) 2014, item 1482]; $\mathrm{Cu}$ and $\mathrm{Pb}$ levels exceeded effluent limits.

Phosphorus and nitrogen, and to a lesser extent Fe, play key roles in primary production (Vollenweider 1976; Kajak 1983). The investigated post-mining lakes are very young compared to glacial lakes, and so have not been supplied with large amounts of phosphorus and nitrogen. Low phosphorus and nitrogen loadings from catchment areas can cause low trophic levels. Delimitation of catchment areas is not yet possible due to lignite mining and/or land reclamation in the vicinity.

In all three lakes, TP and $\mathrm{TSI}_{\mathrm{TP}}$ (55-59) were typical of eutrophic waters; their highest values were recorded in summer. Similar TP levels were observed in 2004 (Staniszewski et al. 2013). The low N:P ratio (4-6), especially in summer, indicates nitrogen limitation of primary production (significant nitrogen deficiency relative to phosphorus). There is a real risk that such a proportion of major biogenic elements will lead to harmful cyanobacterial blooms. Nostocales, the main contributors to this environmental problem, assimilate atmospheric nitrogen (Reynolds 2006) and can therefore eliminate eukaryotic algae from the phytoplankton community. Many species of cyanobacteria, e.g. Anabaena lemmermannii, Anabaena flos-aquae, Aphanizomenon spp., can produce dangerous cyanotoxins. Low numbers of these cyanobacteria have been identified in the studied lakes. Phosphorus concentrations were significantly lower in autumn, winter, and spring.

The highest Chl $a\left(6.28 \mu \mathrm{g} \mathrm{L}^{-1}\right)$ was recorded in the summer in Lake Przykona. In other seasons, the growth of pelagic phytoplankton was low, which resulted in great variability of Chl $a$. In Przykona and Bogdałów, Chl $a$ was within the range typical of mesotrophic water bodies. Lake Janiszew had very low Chl $a$ levels, typical of oligotrophic water bodies ( $\mathrm{TSI}_{\mathrm{Chl} a}=29.5$ ).
A total of 100 taxa of prokaryotic and eukaryotic algae were identified in the studied lignite pit lakes. Diatoms, chlorophytes, and cyanobacteria were represented by the highest numbers of species. Although the lakes had similar species richness, they differed significantly in terms of species composition and phytoplankton biomass. The highest biomass was recorded in Lake Przykona; much lower levels, typical of mesotrophic water bodies (OECD 1982), were observed in Bogdałów, and the lowest in Janiszew. The extremely low phytoplankton biomass in Janiszew throughout this research indicates oligotrophic conditions that may be attributed to strong zooplankton pressure (Schriver et al. 1995). Cladocera constitute more than $50 \%$ of the total zooplankton biomass. It can be assumed that vast algal populations live at greater depths: in lakes with high water transparency, phytoplankton develops further from the surface to avoid excessive UV radiation. In Przykona and Janiszew, diatoms and cryptophytes had the highest average biomass; in Bogdałów, dinoflagellates and cryptophytes were highest.

The low nutrient level limits primary production, as is evident from the low Chl $a$ content, low phytoplankton biomass, and relatively high water transparency. Low abundance and species richness of the zooplankton indicate low trophic levels in all three lakes. According to Karabin (1985) and Radwan (2004), a lake can be classified as mesotrophic if rotifer abundance is less than 400 ind. $\mathrm{L}^{-1}$; Przykona and Janiszew fall in this category. In Bogdałów, rotifer abundance exceeded 400 ind. $\mathrm{L}^{-1}$ in spring and summer (624 and 500 ind. $\mathrm{L}^{-1}$, respectively), which indicates meso-eutrophy. Many authors maintain that rotifer abundance is a good indicator of the trophic state (EjsmontKarabin 2012; May and O'Hare 2005). Similarly, a low contribution of tecta forms to the population of Keratella cochlearis may indicate low trophy (Ejsmont-Karabin 2012). The composition of the dominant species showed the lowest trophy in Janiszew and the highest in Bogdałów.

The results from Lake Przykona are somewhat puzzling: only one rotifer species was identified in Spring, 2012, compared to 12 identified in Summer, 2011. This difference may be due to insufficient or low-quality feed for rotifers or high predator pressure. Full understanding will require further research.

The trophic state of lakes and other water bodies is affected by various factors, including their morphometry and management of their catchment areas (Dodson et al. 2009; Schindler 2006). Determining the trophic state is crucial when making a lake management plan aimed at preserving good water quality for the longest time.

According to Carlson (1977) and Kratzer and Brezonik (1981), Lake Przykona is low meso-eutrophic and Bogdałów is highly mesotrophic. The average TSI in these 
lakes was over 40 (Table 3). Because Bogdałów is small, deep, and stratified in summer, and has the lowest exposure index, anoxic conditions were observed near the bottom, even with low phytoplankton biomass. Lake Janiszew had the lower TSI (average 39), which indicates low mesotrophy.

The relationships between TSI variables in all studied lakes were similar and showed light attenuation caused by algal dominance. However, some factors, such as nitrogen limitation and/or zooplankton grazing, limit algal biomass (Carlson 1983). TSI ${ }_{\text {Rot }}$ indicates that Przykona and Bogdałów fall on the borderline between low and high meso-eutrophy, while Janiszew can be classified as highly mesotrophic (Ejsmont-Karabin 2013).

The results show that the lakes differed from each other in many aspects, but Lakes Bogdałów and Janiszew had similar chemical compositions. Some features of the studied pit lakes are typical of natural lakes, while others, of anthropogenic water bodies. In the near-future, more attention should be paid to the hydrochemistry of the water flowing into the lakes, especially from the lignite mining areas, since this can determine the influence of water quality in these water bodies. Further research seems necessary for a better assessment, with the focus on the growing season (abundant algal growth), i.e. from April to October.

Based on our research, the investigated lakes seem to be sensitive to environmental influences (especially from their catchment areas) due to their small size and depth. Regular monitoring is therefore required to provide the information needed to maintain optimal conditions.

Aquatic organisms require certain environmental conditions. Determining the optimal depth for newly created lakes will affect the activity of aquatic organisms (Soni et al. 2014). It is advised that newly formed lakes should have a depth that is greater than $10 \mathrm{~m}$, depending on their shape and current and expected management of the surrounding area. The optimal depth should be calculated based on long-term observations as well as mathematical formulas and models (Soni et al. 2014). Moreover, the depth of lakes should be maximized over as large an area as possible, to maximize water volume. The ratio of the hypolimnion volume to total lake volume should be as high as possible. It is also obvious that deeper lakes have greater ecological stability. However, mine owners generally insist on the fastest possible reclamation of mined areas and handing it over to local governments. Since open pits can take a very long time (a decade or longer) to fill with water, reducing their depth by filling them in with debris seems more cost-effective. This study, by describing the initial conditions of the lakes (age ranging from 4 to 20 years), forms a basis for future evaluation.

\section{Conclusions}

Our results show that post-mining pit lakes are excellent platforms for investigating community succession and that they enable researchers to test methods traditionally used for studying natural lakes. However, these lakes are sensitive to environmental influences (especially from their catchment areas) due to the small size and depth.

The investigated post-mining lakes are very young compared to glacial lakes and represent early stages of ecosystem succession. Despite different ages and morphometries, they are all mesotrophic and have good water quality. They have not been supplied with large amounts of phosphorus and nitrogen, which can cause excessive development of pelagic phytoplankton; as a result, they share low chlorophyll $a$ content, low phytoplankton biomass, and relatively high water transparency. Low abundance and species richness of zooplankton indicate low trophic levels in all the lakes.

The low N:P ratio, especially in summer, indicates that lack of nitrogen limits primary production. There is a real risk that this ratio of major biogenic elements will lead to harmful cyanobacterial blooms. The relationship between TSI variables in all of the studied lakes were similar and showed that algae dominate light attenuation, and that factors such as nitrogen limitation and zooplankton grazing limit algal biomass.

Presumably, the use of Quaternary deposits (sand, clay) to form the bottoms of the studied pit lakes were responsible for their $\mathrm{pH}(>7)$. More attention should be paid to the hydrochemical regime of waters flowing into the lakes (especially from the mining areas) to determine their influence on water quality in these recently created water bodies.

Newly formed lakes should also have an optimal depth, depending on their shape, and current and expected management of the surrounding areas. The maximum depth should be determined by computer modeling. Shaping the lake basin prior to flooding should consider the location of banks, which, when used as a shield against wind, can positively impact the creation of full thermal stratification.

From an environmental standpoint, creating islands, especially in small, shallow lakes, is highly controversial. Environmental authorities recommend this as a way of providing safe bird habitats. However, in lakes with low trophic state, additional phosphorus loading from bird droppings can accelerate eutrophication.

Catchment boundaries have to be determined to assess the effect of catchment area on the lakes. Effective management is essential to maintain good ecological potential and water quality. Monitoring of recreational housing and 
community development in the areas will provide data on whether/how they affect the lakes. Another step to maintain water quality is to regularly evaluate the nutrient balance, with particular emphasis on phosphorus; if elevated concentrations are noted, procedures to eliminate its sources will have to be adopted.

Open Access This article is distributed under the terms of the Creative Commons Attribution 4.0 International License (http:// creativecommons.org/licenses/by/4.0/), which permits unrestricted use, distribution, and reproduction in any medium, provided you give appropriate credit to the original author(s) and the source, provide a link to the Creative Commons license, and indicate if changes were made.

\section{References}

Axler R, Yokom S, McDonald M, Runke H, Wilcox D, Cady B (1996a) Restoration of a mine pit lake from aquacultural nutrient enrichment. Restor Ecol 6:1-19

Axler R, Larsen C, Tikkanen C, McDonald M, Yokom S, Aas P (1996b) Water quality issues associated with aquaculture: a case study in mine pit lakes. Water Environ Res 68:995-1011

Bastviken D, Persson L, Odham G, Tranvik L (2004) Degradation of dissolved organic matter in oxic and anoxic lake water. Limnol Oceanogr 49:109-116

Berman T (1998) Lake Kinneret and its catchment: international pressures and environmental impacts. Water Policy 1(2):193-207

Bockelmann BN, Fenrich EK, Lin B, Falconer RA (2004) Development of an ecohydraulic model for stream and river restoration. Ecol Eng 22:227-235. doi:10.1016/j.ecoleng.2004.04.003

Brenner F, Edmundson J, Werner M, McGrath T (1987) Plankton, chlorophyll characteristics and fishery potential of surface coal mine lakes in western Pennsylvania. Proc Penns Acad Sci $61: 147-152$

Carlson RE (1977) A trophic state index for lakes. Limnol Oceanogr 22(2):361-369

Carlson RE (1983) Discussion on "Using differences among Carlson's trophic state index values in regional water quality assessment," by Richard A Osgood. Water Resour Bull 19:307-309

Castro JM, Moore JN (2000) Pit lakes: their characteristic and the potential for their remediation. Environ Geol 39(11):1254-1260

Dembowska EA, Napiórkowski P (2015) A case study of the planktonic communities in two hydrologically different oxbow lakes, Vistula River, Central Poland. J Limnol 74(2):346-357. doi:10.4081/jlimnol.2014.1057

Dembowska EA, Napiórkowski P, Mieszczankin T, Józefowicz Sz (2015) Planktonic indices in the evaluation of the ecological status and the trophic state of the longest lake in Poland. Ecol Ind 56:15-22. doi:10.1016/j.ecolind.2015.03.019

Dodson SI, Newman AL, Will-Wolf S, Alexander ML, Woodford MP, Van Egeren S (2009) The relationship between zooplankton community structure and lake characteristics in temperate lakes (northern Wisconsin, USA). J Plankt Res 31(1):93-100. doi:10.1093/plankt/fbn095

Doupé RG, Lymbery AJ (2005) Environmental risks associated with beneficial end uses of mine lakes in southwestern Australia. Mine Water Environ 24:134-138

Dz U (2014) Journal of Laws from 2014, item 1482. rozporzadzenie Ministra Środowiska z dnia 22 października 2014 r. w sprawie klasyfikacji stanu jednolitych części wód powierzchniowych oraz środowiskowych norm jakości dla substancji priorytetowych [in Polish]

Ejsmont-Karabin J (2012) The usefulness of zooplankton as lake ecosystem indicators: Rotifer Trophic State Index. Pol J Ecol 60(2):339-350

Ejsmont-Karabin J (2013) An analysis based on rotifer indices of the effect of water and sewage management on the water quality in the system of interconnected glacial lakes. Limnol Rev 13(4):191-195. doi:10.2478/limre-2013-0021

Elser JJ, Carpenter SR (1988) Predation-driven dynamics of zooplankton and phytoplankton communities in a whole-lake experiment. Oecologia 76(1):148-154

Gammons CH, Harris LN, Castro JM, Cott PA, Hanna BW (2009) Creating lakes from open pit mines: processes and considerations, with emphasis on northern environments. Can Tech Rep Fish Aquat Sci 2826:106

Gammons CH, Pape BL, Parker SR, Poulson SR, Blank C (2013) Geochemistry, water balance, and stable isotopes of a "clean" pit lake at an abandoned tungsten mine, Montana, USA. Appl Geochem 36:57-69. doi:10.1016/j.apgeochem.2013.06.011

Harris RP, Wiebe PH, Lenz J, Skjoldal HR, Huntley M (2000) Zooplankton methodology manual. ICES Academic Press, pp 147-173

Hillebrand H, Dürselen CD, Kirschtel D, Pollingher U, Zohary T (1999) Biovolume calculation for pelagic and benthic microalgae. J Phycol 35:403-424

Hindák F (2008) Colour atlas of cyanophytes. Veda, Publ House of the Slovak Acad of Sciences, Bratislava

Idso SB (1973) On the concept of lake stability. Limnol Oceanogr 18:681-683

Javornickỳ P (2003) Taxonomic notes on some freshwater planktonic Cryptophyceae based on light microscopy. Hydrobiologia 502:271-283. doi:10.1023/b:hydr.0000004285.50172.1f

Kajak Z (1983) Dependences of chosen indices of structure and functioning of ecosystems of different trophic status and mictic type for 42 lakes. Ecological characteristics of lakes in northeastern Poland versus their trophic gradient. Ekol Pol 31:495-530

Karabin A (1985) Pelagic zooplankton (Rotatoria + Crustacea) variation in the process of lake eutrophication. I. structural and quantitative features. Ecol Pol 33:567-616

Klapper H, Geller W (2001) Water quality management of mining lakes-a new field of applied hydrobiology. Acta Hydrochim Hydrobiol 29:363-374

Komárek J, Anagnostidis K (2007) Cyanoprokaryota 2. Teil/2nd Part: Oscillatoriales. In: Büdel B, Gärtner G, Krienitz L, Schagerl M (eds) Süßwasserflora von Mitteleuropa b. 19/2. Spektrum Akademischer, Verlag, Heidelberg

Komárek J, Anagnostidis K (2008) Cyanoprokaryota 1. Teil/1st Part: Chroococcales. In: Ettl H, Gerloff J, Heynig H, Mollenhauer D (eds) Süßwasserflora von Mitteleuropa b. 1/19. Spektrum Akademischer, Verlag, Heidelberg

Komárek J, Fott B (1983) Chlorophyceae (Grünalgen), O. Chlorococcales. Die Binnengewässer. Das Phytoplankton des Süßwassers, Systematik und Biologie, 7 Teil 1, Hälfte, Stuttgart, Schweizerbart'sche Verlagsbuchhandlung (Nägele uObermiller) (in German)

Komárek J, Zapomèlova E (2007) Planktic morphospecies of the Cyanobacterial genus Anabaena = subg, Dolichosperum-1. Part: coiled types. Fottea. Olomouc 7(1):1-31

Kovach WL (2010) MVSP-a multivariate statistical package for windows, ver. 3.2, Kovach Computing Service, Pentraeth, Wales

Krammer K, Lange-Bertalot H (1986) Bacillariophyceae. 1. Teil: Naviculaceae. In: Ettl H, Gerloff J, Heynig H, Mollenhauer D (eds) Süßwasserflora von Mitteleuropa b 2/1, Gustav Fischer Verlang, Stuttgart (in German) 
Krammer K, Lange-Bertalot H (1988) Bacillariophyceae. 2. Teil: Bacillariaceae, Epithemiaceae, Surirellaceae. In: Ettl H, Gerloff J, Heynig H, Mollenhauer D (eds) Süßwasserflora von Mitteleuropa b 2/2, Gustav Fischer Verlang, Stuttgart (in German)

Krammer K, Lange-Bertalot H (1991a) Bacillariophyceae. 3. Teil: Centrales, Fragilariaceae, Eunotiaceae. In: Ettl H, Gerloff J, Heynig H, Mollenhauer D (eds) Süßwasserflora von Mitteleuropa b 2/3, Gustav Fischer Verlang, Stuttgart (in German)

Krammer K, Lange-Bertalot H (1991b) Bacillariophyceae. 4. Teil: Achnanthaceae, Ktitische Ergänzungen zu Navicula (Lineolatae) und Gomphonema Gesamtlit-eraturverzeichnis. In: Ettl H, Gärtner G, Gerloff J, Heynig H, Mollenhauer D (eds) Süßwasserflora von Mitteleuropa b 2/4 Gustav Fischer Verlang, Stuttgart (in German)

Kratzer CR, Brezonik PL (1981) A Carlson-type trophic state index for nitrogen in Florida lakes. Water Res Bull 17:713-715

LAWA - LÄNDERARBEITSGEMEINSCHAFT WASSER (1998) Gewässerbewertung —-stehende Gewässer. Vorläufige Richtlinie für eine Erstbewertung von natürlich enstandenen Seen nach trophischen Kriterien Kulturbuch-Verlag, Berlin (German)

Marszelewski W (2001) Lakes of the Dobrzyńskie Lakeland, UMK Press, Torun

May L, O'Hare M (2005) Changes in rotifer species composition and abundance along a trophic gradient in Loch Lomond, Scotland, UK. Hydrobiologia 546:397-404. doi:10.1007/1-4020-4408-941

McCauley E (1984) The estimation of abundance and biomass of zooplankton in samples. In: Downing JA, Rigler FH (eds) A manual on methods for assessment of secondary productivity in fresh waters, IBP Handbook, 17, Blackwell Scientific Publ, Hoboken

Mietz O (1991) Allgemeine limnologische Charakteristik von 12 Potsdamer Landseen unter besonderer Berücksichtingung des Einflusses von topographischen und morphometrischen Parametern auf den Chlorophyll-a-Gehalt. Diss, Humboldt Universität, Berlin

Müller B, Bryant LD, Matzinger A, Wüest A (2012) Hypolimnetic oxygen depletion in eutrophic lakes. Environ Sci Technol 46:9964-9971. doi:10.1021/es301422r

Nixdorf B, Lessmann D, Denke R (2005) Mining lakes in a disturbed landscape: application of the EC water framework directive and future management strategies. Ecol Eng 24:67-73. 10.1016/j. ecoleng.2004.12.008

Nogrady T, Wallance RL, Snell TW (1993) Rotifera, biology, ecology and systematics-vol. 4. In: Dumont HJF (ed) Guides to the Identification of the Microinvertebrates of the Continental Waters of the World. SPB Academic Publ, Amsterdam

Nusch EA (1980) Comparison of different methods for chlorophyll and phaeopigment. Arch Hydrobiol Beih Ergebn Limnol Stuttgart 14:14-16

OECD (1982) Eutrophication of waters, monitoring, assessment and control. Org for economic cooperation and development, Paris

Osgood RA (1988) Lake mixis and internal phosphorus dynamics. Arch Hydrobiol 113(4):629-638

Patalas K (1984) Mid-summer mixing depths of lakes of different latitudes. Int Ver Theor Angew Limnol Verh 22:97-102

Polak K, Klich J (2009) Water reclamation conditions in post-mining lands based on the Przykona water reservoir, Biul PIG 436: 373-378

Popovskỳ J, Pfiester LA (1990) Dinophyceae (Dinoflagellida). In: Ettl H, Gerloff J, Heynig H, Mollenhauer D (eds) Süßwasserflora von Mitteleuropa B 6, Gustav Fischer Verlang, Jena, Stuttgart

Radwan S (2004) Polish Freshwater Fauna: 32 A and 32B. Wrotki. Rotifera. Tercja Press, Łódź (in Polish)
Reynolds CS (2006) Ecology of Phytoplankton. Cambridge Univ Press, UK

Rybak JI, Błędzki LA (2010) Freshwater Planktonic Crustacea, WUW Warsaw (in Polish)

Schindler DW (2006) Recent advances in the understanding and management of eutrophication. Limnol Oceanogr 51:356-363. doi:10.4319/lo.2006.51.1

Schmidt W (1928) Über Temperatur-Und Stabilitätsverhältnisse von Seen. Geogr Ann 10:145-177

Schriver PER, Bogestrand J, Jeppesen E, Sondergaard M (1995) Impact of submerged macrophytes on fish-zooplankton-phytoplankton interactions: large-scale enclosure experiments in a shallow eutrophic lake. Freshwater Biol 33(2):255-270

Schultze M, Pokrandt K-H, Hille W (2010) Pit lakes of the central German lignite mining district: creation, morphometry and water quality aspects. Limnologica 40:148-155. doi:10.1016/j. limno.2009.11.006

Solarczyk A (2013) Differentiation of the oxygen regime of the lakes in the Brodnica Lakeland. Diss, Nicolaus Copernicus Univ, Torun

Soni AK, Mishra B, Singh S (2014) Pit lakes as an end use of mining: a review. J Min Environ 5(2):99-111

Staniszewski R, Sobczyński T, Dominiak M (2013) Zmienność wybranych wskaźników jakości wody zbiornika powyrobiskowego Przykona. In. Diagnozowanie stanu środowiska. Metody badawcze - prognozy. (ed) Garbacz JK BTN Bydgoszcz 7:295-304 (in Polish)

Starmach K (1968) Chrysophyta I. Chrysophyceae - złotowiciowce oraz wiciowce bezbarwne - zooflagellata wolnożyjące. In: Starmach K (ed), Flora Słodkowodna Polski, Tom 5. Państwowe Wydawnictwo Naukowe, Warszawa (in Polish)

Starmach K (1974) Cryptophyceae-kryptofity, Dinophyceaedinofity, Raphiophyceae-rafidofity. In: Starmach K (ed) Flora Słodkowodna Polski, Tom 4, Państwowe Wydawnictwo Naukowe, Warszawa (in Polish)

Starmach K (1983) Euglenophyta - eugleniny. In: Starmach K (ed) Flora Słodkowodna Polski, Tom 3, Państwowe Wydawnictwo Naukowe, Warszawa, Kraków (in Polish)

Sun J, Liu D (2003) Geometric models for calculating cell biovolume and surface area for phytoplankton. J Plankton Res 25(11):13311346. doi:10.1093/plankt/fbg096

Utermöhl H (1958) Zur Vervollkommung der quanitativen Phytoplankton- Methodik. Mitt Internat Verein Limnol 9:1-38

Ventz D (1974) Die Einflußnahme von Umgebungsfaktoren und morphometrischen Faktoren auf den Stoffhaushalt von Seen. Diss, Dresden University

Vollenweider RA (1976) Advances in defining critical loading level for phosphorus in lakes eutrophication. Mem Inst Ital Idrobiol 33: $53-83$

Wetzel RG (2001) Limnology: lake and river ecosystems. Academic Press, Cambridge, MA

Winder M, Schindler DE (2004) Climate change uncouples trophic interactions in an aquatic ecosystem. Ecology 85(8):2100-2106

Wołowski K (1998) Taxonomic and environmental studies on Euglenophytes of the Kraków-Częstochowa Upland (Southern Poland). Fragm Flor Geobot, Suppl 6:1-192

Wołowski K, Hindák F (2005) Atlas of Euglenophytes. Veda, Publ House of the Slovak Acad of Sciences, Bratislava

Zauke GP, Bohlke J, Żytkowicz R, Napiórkowski P, Giziński A (1998) Trace metals in trypton, zooplankton, zoobentos, reeds and sediments of selected lakes in North-Central Poland. Int Rev Hydrobiol 83(5-6):501-526 